\title{
THE IMPERIAL SOCIETY OF HISTORY AND RUSSIAN ANTIQUITIES AND ITS DEVELOPMENT OF BULGARIAN RESEARCH ${ }^{1}$
}

\section{Abstract:}

The article discusses the history of the Society of History and Russian Antiquities (SHRA,1804-1929), highlights its academic and publishing activities in the first half of the 19th century in relation to the study of Bulgarian issues. On the basis of this material it is concluded that the SHRA aimed at increasing the prestige and development of national historical academic research and contributed to the formation of an academic community of people passionate about the ideas of knowledge and national service: a "scholarly community". Although Bulgarian research was not dominant in Slavic scholarship which was actively developed by the SHRA members from the 1830s, its emergence testified to increasing interest in the Bulgarian people. The work of the SHRA contributed to the accumulation of knowledge about and understanding of the Bulgarian people, their history and culture.

\section{Keywords:}

Imperial Society of History and Russian Antiquities, N.M. Karamzin, Y.I. Venelin, A.D. Chertkov, O.M. Bodyansky, V.M. Undolsky, V.I. Grigorovich, P.A. Bessonov.

АННОТацИя: М.М. ФРОЛОВА. «ИМПЕРАТОРСКОЕ ОБЩЕСТВО ИСТОРИИ И ДРЕВНОСТЕЙ РОССИЙСКИХ И РАЗВИТИЕ В НЕМ БОЛГАРИСТИЧЕСКИХ ИССЛЕДОВАНИЙ».

В статье рассматривается история создания Императорского Общества истории и древностей российских (ОИДР,1804-1929), освещается его научная и издательская деятельность в первой половине XIX в. в формате изучения болгарской проблематики. На основе приведенного материала делается вывод о том, что ОИДР, нацеленное на повышение престижа и развитие отечественной исторической науки, способствовало формированию сообщества людей, увлеченных идеями познания и национального служения - «ученого содружества». И хотя болгарские сюжеты не были доминирующими в славянской проблематике, активно разрабатывавшейся членами ОИДР с 1830-х годов, но их появление свидетельствовало об увеличении познавательного интереса к болгарскому народу. Деятельность ОИДР способствовала накоплению знаний о болгарском народе, его истории и культуре и их осмыслению.

\section{Ключевые слова:}

Императорское Общество истории и древностей российских, Н.М. Карамзин, Ю.И. Венелин, А.Д. Чертков, О.М. Бодянский, В.М. Ундольский, В.И. Григорович, П.А. Бессонов.

\footnotetext{
1 The work was carried out with the financial support of the RFBR (grant № 18-512-76004).
} 
The Society of History and Russian Antiquites (SHRA, 1804-1929) is one of the oldest academic societies in Russia, originated at Moscow University with the purpose of the study and critical publication of Russian chronicles and played an important role in the development of Slavic studies in Russia in the first half of the 19th century.

From the very beginning of its existence, the society was not limited to the publication of Russian chronicles: it entrusted its members with the task of searching out information concerning "the Slavic peoples from ancient historians." Publication of its materials by the SHRA was significantly hampered for a long time a lack of a solid financial base, since contributions from members of the society and donations were its main source of funds. However, in 1837 it received imperial status and annual funding in the amount of five thousand rubles in silver.

South Slavic themes began to emerge in the society a decade and a half after its creation. In 1818 the SHRA correspondent major P.F. Gorenkin sent along his study, "On the Antiquity of Slavonic Writing," which stated that Cyril and Methodius had not created a new alphabet but had only "fixed what the Slavs had previously used" and that the modern Bulgarian language was close to Church Slavonic. Interest in the history and writing of the southern Slavs increased in the 1830s, after Russia's brilliant victory over Turkey in the war of 1828-29. The SHRA report for 1837 referenced Y.I. Venelin's work studying the history of the Bulgarians and other Slavic peoples.

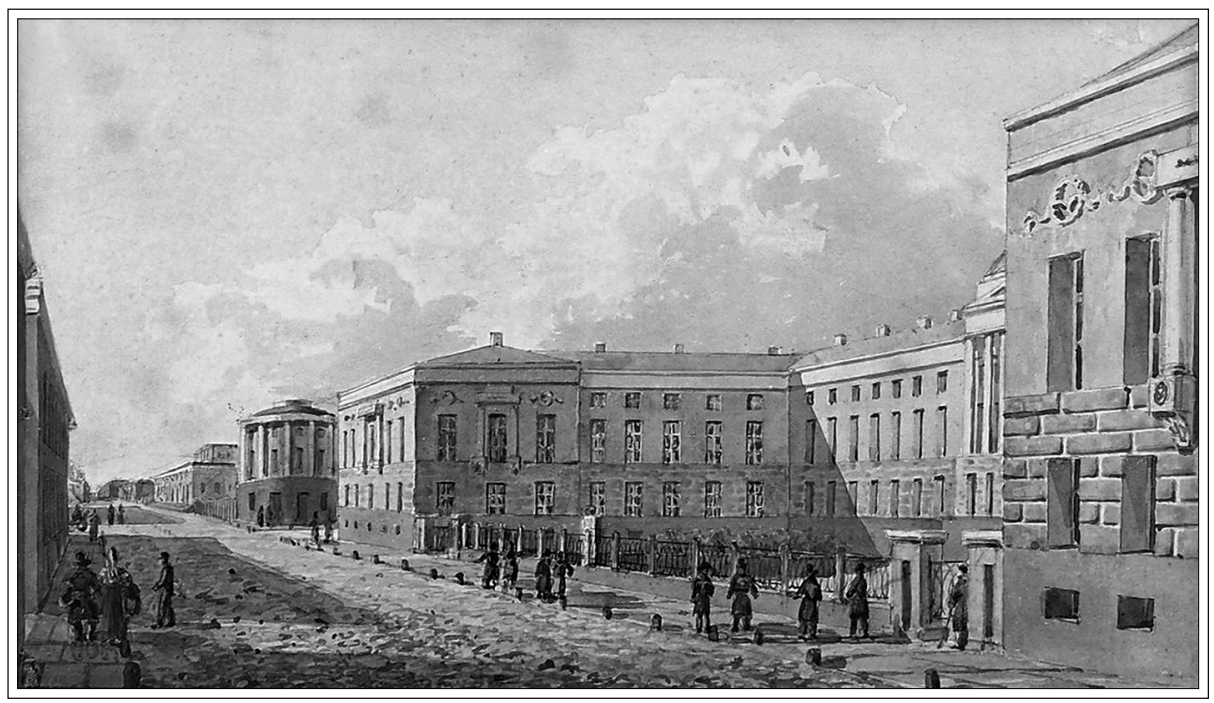

"View of Mokhovaya street.

The building of the Moscow Imperial University."

Paper, watercolor. Unknown artist, 1830s 
In the early 1840 s, the vice president of the society A.D. Chertkov, made four reports on his research on the Glossary of the Vatican List of the Bulgarian Translation (14th century) by the Byzantine Chronicle of Constantine Manasses (12th century), famous for its 69 miniatures. The scholar copied the glossaries of this list in the Vatican in 1839, and then found another list of the Bulgarian translation of this document in the Synodal Collection of the Patriarchal Library in Moscow and conducted a comparative analysis of both lists. He later published two monographs on the history and culture of medieval Bulgaria: On the translation of the Manassine chronicle into Slovenian, according to two lists: from the Vatican and from the Patriarchal Library, with an essay on the history of the Bulgarians and Description of the war of Grand Duke Svyatoslav Igorevich against the Bulgarians and Greeks in 967-971. These were published in the Russian Historical Collection and became a significant event in Russian pre-revolutionary Bulgarian studies. Unfortunately, the decision of the SHRA to publish the text of the Bulgarian translation of the chronicle, adopted on 21 December 1840, was not fulfilled.

After O.M. Bodyansky, an extraordinary professor in the department of History and Literature of Slavic dialects at Moscow University, was elected secretary of the journal, by virtue of the academic's professional pursuits, the journal started to contain more materials devoted to South Slavic issues. In 1846 the publication of the Vinodolsky Law of 1288 appeared: one of the most ancient documents of South Slavic lawmaking. Bodyansky also translated an article by Czech scholar F. Palatsky, Comparison of the laws of Tsar Stefan Dushan of Serbia with the oldest Zemstvo decrees of the Czechs.

Issues concerning Cyril and Methodius became a constant for SHRA; among the articles devoted to this topic was one written by the Bishop of Riga, Philaret (D.G. Gumilevsky). V.M. Undolsky (1815-64), another scholar, bibliographer and archeographer, elected librarian of the SHRA in 1847, was one of the first in Russia to study the creative legacy of Clement of Ohrid, a Bulgarian enlightener and disciple of Cyril and Methodius. At a meeting of the SHRA in 1845, Undolsky presented a plan to publish the works of St Clement, and two years later he read his article, Constantine, Bishop of Bulgaria, Methodius's disciple. However, the materials collected by Undolsky were published only in 1895.

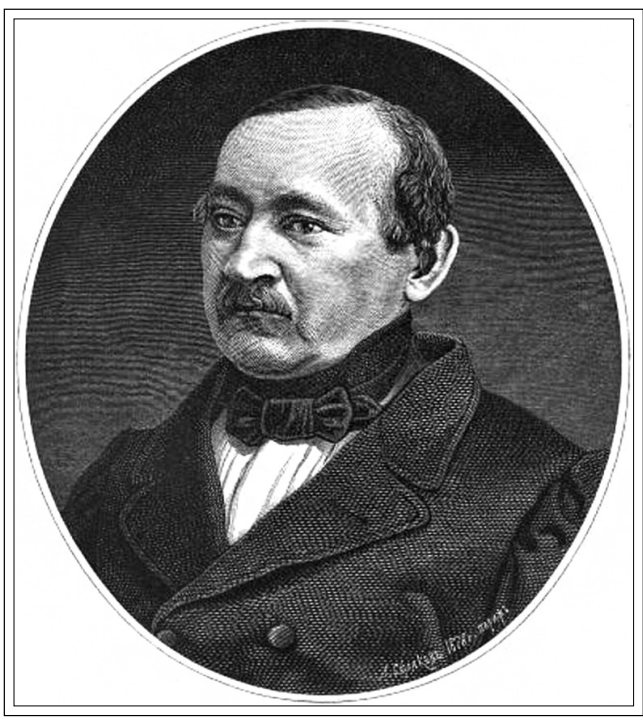

Osip M. Bodyansky 
In 1848 Bodyansky published his translation of P. Shafarik's report, The Flowering of Slavic Writing in Bulgaria, which he had done a year earlier at the Royal Czech Academic Society, in the journal "Readings in SHRA." It contained biographical information about Cyril and Methodius, their disciples Clement, Naum, Angelarius, Sava and Gorazd and the successors of the latter: Constantine, Gregory, John the Exarch of Bulgaria, Chernorizets Chrabar and others.

In 1846 M.A. Obolensky, director of the Moscow archives of the Ministry of Foreign Affairs, presented the article On the Greek code of George Hamartolos stored in the Moscow Synodal Library, and on the Serbian and Bulgarian translations of his chronicle. He emphasized in it the need to study the works of Byzantine chroniclers in Slavic translations and Slavic chronographs.

Members of the SHRA were attracted by the topic of the settlement of the ancient Slavs in the Balkans and Europe. The aforementioned Bishop of Riga Philaret wrote about this in his work The Holy Great Martyr Demetrius the Solun and the Slavs of Solun. Chertkov actively developed a hypothesis about the ancestral homeland of the Slavs. Even as far back as 1842 he read a report at an SHRA meeting entitled On the territory of the ancestors of the Slavs in the countries beyond the Damube. His research on the issue of Slavic ethnogenesis, On the resettlement of the Thracian tribes across the Damube and further to the North, to the Baltic Sea and to us in Russia, was published in five books of the "SHRA Annals": Books 10, 13, 16, 23, 25.

V.I. Grigorovich, professor in the department of History and Literature of Slavic dialects at Kazan University, made a trip to the Balkans in 1844-47 and agreed to publish two manuscripts he brought back: South Slavic Monuments of the 15th Century: Two Letters of Stephen Voevoda of Moldowalachia and Dorotheus, Archbishop of the First Justinian, i.e., Obrid (from the manuscripts of St Ivan of Rila Monastery).

A lot of material about the Bulgarians was contained in the 21st book of the annals. In the article, On some years of the Nestor Chronicle, historian D.N. Dubensky noted that "the March calculation came to us from the Bulgarians." Then followed a study by historian S. N. Palauzov, Synodicon of Tsar Boril according to the manuscript of the 14th century. The "Materials" section contained Bulgarian songs from the collection of Yu. I. Venelin, N.D. Katranov and other Bulgarians. A collection of Bulgarian folk songs with explanation and research was presented by Moscow University candidate, P.A. Bessonov. At a meeting on 30 April 1854 this study was read and the author was elected to the society's associate members.

The "Materials" section of the next, 22nd book of "The Annals" included a second edition of the Collection of Bulgarian Songs, which was provided with a general index of the songs and an explanation of the obscure words found in them.

On 30 March 1856 Bessonov submitted a written proposal on the election of A.F. Hilferding, who presented four of his books and ten Latin letters, "relating to 
the history of the Serbs at the house of Nemanya, copied by him in the Vienna Archive and explanation in the appendix." Bessonov pointed out the significance of these letters, emphasizing their importance for the history of all Slavs and the Russian enlightenment.

The SHRA library was constantly replenished with books on Slavic topics. In 1829 Serbian scholar V. Karadzhich sent the first volume of L.Von Ranke's Serbian Revolution, from Vienna and in 1837, his work on Montenegro. In 1840 the book Serbian Monuments, by Belgrade priest Pavel Tvrtkovich was delivered and two years later the publications Bulgarian Scribes and The Day Soldier of Bulgarian Education by Bulgarian merchant V.E. Aprilov. The society was known in distant Montenegro, from where, in 1855, writer and historian Milorad Medakovich sent his essay entitled The Story of Montenegro from the Earliest Time until 1830.

The SHRA established ties with many Slavic scholars; among them was the Serb V. Karadzhich. In 1845 Serbian Prince Alexander Karageorgievich, Petar Negosh, the Metropolitan of Montenegro, and "Serbian historian and poet" Sima Milutinovich were elected honorary members of the society. The SHRA established contact with South Slavic academic societies and organizations - the Serbian Academic Society in Belgrade and the Matitsa Croatian in Zagreb, organizing an active exchange of literature with them.

N.M. Karamzin, author of the famous work, The History of the Russian State, did not believe in the effectiveness of the collective work of scholars, but the practice of the SHRA from the 1830s-50s justified this form of association between historians: it created new areas of academic cooperation, facilitated greater exchange of academic information and familiarity with academic criticism by their colleagues.

The SHRA neither controlled the academic creativity of its members and nor dictated their research topics. The famous historian I.E. Zabelin claimed that members of the society were free to choose topics, and it depended on happenstance. However, even unusual works, in his words, reflected "the direction and tastes of the scholars of their time." In the first half of the 19th century, South Slavic subjects did not figure prominently among the issues that SHRA members were actively pursuing. However, starting in the early 1850 s there was an observable increase in their number. Due to the growth in SHRA's publishing activity, the results of the research of its full members were widely disseminated in Russian society and abroad and became socially significant. The activities of SHRA as a whole contributed to the accumulation of knowledge about the South Slavs, their history and written culture. 


\section{BIBLIOGRAPHY}

Popov NA. Istoriya imperatorskogo Moskovskogo obshchestva istorii i drevnostey rossiyskikh. 1804-1812 gg. Ch. 1. Moscow, 1884. $256 \mathrm{s.}$

Frolova, M.M. "Obshchestvo istorii i drevnostey rossiyskih i slavyanskaya problematika (1848-1857).” Slavyanovedeniye, 2012, № 2. S. 86-101.

\section{ILLUSTRATIONS}

1. "View of Mokhovaya street. The building of the Moscow Imperial University". 1830s. Paper, watercolor. Unknown artist.

2. The title page of the first issue of the journal "Notes and works of SHRA" (Moscow, 1815) with a portrait of August-Ludwig Slletser on the frontispiece.

3. Osip M. Bodyansky.

4. Palatsky, Frantishek.

5. Undolsky, Vukol Mikhailovich.

6. A portrait of Prince Mikhail Andreevich Obolensky. Artist K.P. Bryullov, 1840.

7. Grigorovich, Viktor Ivanovich.

8. Bessonov, Peter Alekseevich.

9. The title page of the magazine "Readings in SHRA."

10. The title page of the magazine "Vremennik SHRA."

11. The title page of the work of P.A. Bessonov "Bulgarian songs from the collection of Y.I. Venelin, N.D. Katranov and other Bulgarians." VSHRA, 1855, Book 21. 